\title{
Molecular Characterization of Arabica and Conilon Coffee Plants Genotypes by SSR and ISSR Markers
}

\author{
Ludymila Brandão Motta ${ }^{1}$, Taís Cristina Bastos Soares ${ }^{2 *}$, Maria Amélia Gava Ferrão ${ }^{3}$, \\ Eveline Teixeira Caixeta ${ }^{4}$, Rodrigo Monte Lorenzoni ${ }^{5}$ and José Dias de Souza Neto ${ }^{6}$ \\ ${ }^{1}$ Programa de Pós-graduação em Produção Vegetal; Universidade Federal do Espírito Santo; Alegre - \\ ES - Brasil. ${ }^{2}$ Departamento de Farmácia e Nutrição; Universidade Federal do Espírito Santo; Alegre - \\ ES - Brasil. ${ }^{3}$ Empresa Brasileira de Pesquisa Agropecuária, Embrapa Café/Incaper; Vitória - ES - Brasil. \\ ${ }^{4}$ Empresa Brasileira de Pesquisa Agropecuária, Embrapa Café; Viçosa - MG - Brasil. ${ }^{5}$ Universidade \\ Federal do Espírito Santo; Alegre - ES - Brasil. ${ }^{6}$ Programa de Pós-graduação em Genética e \\ Melhoramento; Universidade Federal do Espírito Santo; Alegre - ES - Brasil
}

\begin{abstract}
The molecular characterization of ten genotypes of the Coffea arabica plants and of seven genotypes of $\mathrm{C}$. canephora having interesting features for coffee breeding programs was carried to select the parents for breeding. A total of 40 SSR and 29 ISSR primers were used. The primers generated a total of 331 (307 polymorphic and 24 monomorphic) bands. Analysis of genetic diversity presented dissimilarity intervals ranging from 0.22 to 0.44 between the Conilon genotypes, from 0.02 to 0.28 between the Arabica genotypes, and from 0.49 to 0.60 between the genotypes of the two species in the joint analysis. Four groups were formed: $I=$ genotypes of $\mathrm{C}$. arabica, $I I=$ four progenies of $\mathrm{C}$. canephora, Conilon group, and one non defined C. canephora (Conilon or Robusta), III = one progeny of un-defined C. canephora (Conilon or Robusta) and IV = one progeny of $\mathrm{C}$. canephora of Robusta group. The grouping formed was consistent with the origins of each group. High stabilities of the bifurcations were found by bootstrap analysis. The use of molecular markers of the SSR and ISSR types in the diversity study was efficient in distinguishing genotypes between and within $\mathrm{C}$. arabica and $\mathrm{C}$. canephora.
\end{abstract}

Key words: Coffea Arabica, Coffea canephora, genetic diversity, molecular markers

\section{INTRODUCTION}

The domestication of species, culminating in the successive reduction of genetic diversity, can be mitigated through the use of traditional breeding tools, such as the introduction and selection of germplasm, hybridizations, and backcrosses (Hendre and Aggarwal 2007). The selection of superior genotypes of coffee requires an insightful work. The coffee plant is a perennial crop in which many traits are expressed by mutual actions of multiple genes and by their interaction with the environment. This hinders a more immediate identification of the genetic material traits of interest (Ferrão et al. 2007).

Assessing genetic variability has a great importance in breeding programs. Molecular markers allow direct access to the genome sequences and, thus, isolate the genetic variation of the environmental interferences (Ferrão et al. 2007). The potential use of the Simple Sequence Repeats (SSR) and Inter-Simple Sequence Repeats (ISSR), microsatellite primers, has been demonstrated for Coffea related with genetic

*Author for correspondence: tais@cca.ufes.br 
diversity of native species and germplasm bank accessions, geographical origin detection, domestication degree, coffee plant dispersion history, species identification and genealogy (Masumbuko and Bryngelsson 2006; LopezGartner et al. 2009; Tshilenge et al. 2009; Missio et al. 2010; Setotaw et al. 2010; Mishra et al. 2011). The good prospects presented by the application of ISSR and SSR markers to assess the diversity in Coffea have led to this study. Thus, the aim of the study was the molecular characterization of $C$. arabica and C. canephora genotypes by the molecular markers SSR and ISSR to assist in selecting parents for breeding.

\section{MATERIAL AND METHODS}

Seventeen coffee genotypes of the breeding program of the Instituto Capixaba de Pesquisa, Assistência Técnica e Extensão Rural (Incaper) were used in the study. Ten Arabica coffee plant materials were collected from the Experimental Farm of Venda Nova do Imigrante-ES and seven of Conilon coffee plants were collected from the Bananal do Norte Experimental Farms-ES. Some distinctive characteristics of the materials are presented in Table 1.

Young, healthy, and fully-expanded leaves from the 17 genotypes were collected in the field and used for DNA extraction using the protocol proposed by Doyle and Doyle (1990) modified by Abdelnoor et al. (1995) for C. canephora and the protocol proposed by Diniz et al. (2005) for $C$. arabica with slight modification in which the leaves were macerated in liquid nitrogen, rather than lyophilized. The quality and quantity of the DNA extracted were tested on $0.8 \%$ agarose gel in 1X TBE buffer ( $\mathrm{pH}$ 8.3) (Tris-Borate-EDTA), stained with ethidium bromide $(0.25 / \mathrm{mL})$ and visualized under UV light.

Table 1 - List of the genetic materials of Coffea arabica and Coffea canephora used in the study of molecular characterization.

\begin{tabular}{|c|c|}
\hline \multicolumn{2}{|r|}{ Coffea arabica } \\
\hline Genetic materials & Short description \\
\hline 'Bourbon Amarelo' & Progeny selected in a 'Bourbon Vermelho' tillage, susceptible to rust, high. \\
\hline 'Bourbon Amarelo Nanicão' & Progeny selected in a 'Bourbon Vermelho' tillage, susceptible to rust, short. \\
\hline 'Icatu Amarelo' & $\begin{array}{l}\text { Progeny originated from } C \text {. arabica } \mathrm{x} C \text {. canephora natural crossing, } \\
\text { moderately resistant to rust, tall. }\end{array}$ \\
\hline 'Caturra Amarelo' & Progeny selected in a 'Bourbon' tillage, susceptible to rust, short. \\
\hline 'Mundo Novo' & $\begin{array}{l}\text { Progeny originated from 'Sumatra' } \mathrm{x} \text { 'Bourbon Vermelho'natural crossing, } \\
\text { susceptible to rust, high. }\end{array}$ \\
\hline 'Catuaí Vermelho’ & $\begin{array}{l}\text { Progeny originated from 'Caturra Vermelho' } x \text { ' Mundo Novo' artificial } \\
\text { crossing, susceptible to rust, short. }\end{array}$ \\
\hline 'Iapar 59’ & $\begin{array}{l}\text { Progeny originated from 'Villa Sarchi' x 'Híbrido de Timor' artificial } \\
\text { crossing, rust resistant, short. }\end{array}$ \\
\hline 'Bourbon Verı & Progenies selected in an over 40 years tillage in ES, high adaptability, high. \\
\hline ho II' & \\
\hline on Vermelho Nanicão' & Progeny selected in an over 40 years tillage in ES, high adaptability, short. \\
\hline \multicolumn{2}{|r|}{ Coffea canephora } \\
\hline 'Progênie 03' & d clone, Conilon characteristics, early maturation. \\
\hline 'Progênie 83' & $\begin{array}{l}\text { Improved clone, Conilon/Robusta characteristics, intermediate to late } \\
\text { maturation. }\end{array}$ \\
\hline 'Progênie & Improved clone, Conilon characteristics, late maturation. \\
\hline 'Progênie Bukobensis04' & $\begin{array}{l}\text { Improved clone, Conilon characteristics, small leaf, thin and light, drought } \\
\text { tolerant, early maturation. }\end{array}$ \\
\hline 'Progênie Robu & Improved clone, Robusta characteristics, late maturation. \\
\hline 'Progênie Robusta Precoce' & $\begin{array}{l}\text { Clone introduced by producer, Conilon/Robusta characteristics, super early } \\
\text { maturation. }\end{array}$ \\
\hline 'Progênie Conilon JP' & Clone selected by producer, Conilon characteristics, early maturation. \\
\hline
\end{tabular}

To analyze the genetic diversity of the genotypes of $C$. arabica and $C$. canephora, heterologous amplification of 71 SSR primer pairs was developed for $C$. arabica in the $C$. canephora genotypes (data not published). To carry out the analyses in all the genetic materials, primers 
showing amplification of well-defined bands were selected. Thus, 40 SSR primers, available in the literature, were used (Combes et al. 2000; Rovelli et al. 2000; Baruah et al. 2003; Coulibaly et al. 2003; Moncada and Mccouch 2004; Poncet et al. 2004; Missio et al. 2009a), as well as 29 ISSR primers of the UBC series in the 17 Coffea genotypes (Tables 2 and 3).

PCR reactions for the SSR markers were made in $20 \mu \mathrm{L}$ containing $2.0 \mu \mathrm{L}$ of $10 \mathrm{x}$ buffer, $150 \mathrm{mM} / \mathrm{L}$ of dNTP, $0.1 \mathrm{mM} / \mathrm{L}$ of each primer, $50 \mathrm{ng}$ of DNA, $1 \mathrm{mM} / \mathrm{L} \mathrm{MgCl} 2,0.6 \mathrm{U}$ Taq DNA polymerase and the remaining volume was completed with water (MISSIO et al. 2009b). The amplification reactions of the SSR primers were performed using a 96 Veriti Applied Biosystems thermocycler by a touchdown PCR procedure as Missio et al. 2009b modified. This consisted of initial denaturation at $94^{\circ} \mathrm{C} / 2 \mathrm{~min}$, followed by 10 cycles of denaturation at $94^{\circ} \mathrm{C} / 30 \mathrm{~s}$, annealing of $66^{\circ} \mathrm{C}$ to $57 / 30 \mathrm{~s}$, decreasing $1^{\circ} \mathrm{C}$ in each cycle, and extension at $72^{\circ} \mathrm{C} / 30 \mathrm{~s}$. The last 30 cycles were $94^{\circ} \mathrm{C} / 30 \mathrm{~s} 57^{\circ} \mathrm{C} / 30 \mathrm{~s}$ and $72^{\circ} \mathrm{C} / 30 \mathrm{~s}$, followed by a final extension at $72^{\circ} \mathrm{C} / 8 \mathrm{~min}$. The samples were run on polyacrylamide gel $(6 \%)$ in the presence of $1 \mathrm{X}$ TBE buffer. The electrophoretic separation was done for $2 \mathrm{~h} 30 \mathrm{~min}$ at 100 volts. At the end of the run, the gels were stained in ethidium bromide solution $(0.25 \mathrm{mg} / \mathrm{mL})$.

The amplification reactions of the ISSR primers were performed in a Analítica/Techne/TC-412 thermocycler in a total volume of $20 \mu \mathrm{L}$ containing $2.0 \mu \mathrm{L}$ of $10 \mathrm{x}$ buffer, $1 \mathrm{mM} / \mathrm{L}$ of each
dNTP, $0.2 \mathrm{mM} / \mathrm{L}$ primer, $30 \mathrm{ng}$ DNA, $5 \mathrm{mM} / \mathrm{L}$ $\mathrm{MgCl} 2,1 \mathrm{U}$ of Taq DNA polymerase and the remainder of the volume was completed with water. The program used consisted of initial denaturation at $94^{\circ} \mathrm{C} / 4$ min, 35 cycles of denaturation at $94^{\circ} \mathrm{C} / 1 \mathrm{~min}$, annealing at $52^{\circ} \mathrm{C} / 1$ min, extension at $72^{\circ} \mathrm{C} / 2 \mathrm{~min}$, followed by final extension at $72^{\circ} \mathrm{C} / 7 \mathrm{~min}$. The fragments were applied on $2 \%$ agarose gel. All the images of the fragments obtained in the gels were photodocumented (Locus Biotechnology) using the LPIx Image program.

To record the molecular data for the markers, a binary values matrix was prepared, where code " 0 " referred to absence and "1" to presence of amplification of a fragment (Cruz 2008). This strategy allowed the performance of a statistical analysis of diversity between the species of different ploidy and of dominant and multi-allelic markers (Powell et al. 1996; Souza et al. 2008; Vieira 2010). The genetic similarity values were estimated by the complement of the Jaccard similarity index and clustering analysis by the Unweighted Pair Group Method Arithmetic Mean (UPGMA). The coefficient of variation obtained with the bootstrap analysis was measured to verify the degree of association between the genetic similarity matrix and the dendrogram was generated by this re-sampling method with 1000 simulations. Thus, it was possible to evaluate the stability of bifurcations formed with the aid of the program Genes 2011.9.0 (Cruz 2008).

Table 2 - List of the 29 ISSR primers used for molecular characterization of Coffea arabica and Coffea canephora.

\begin{tabular}{llll}
\hline Primer & Sequência (5'-3') & Primer & Sequência (5'-3') \\
\hline UBC808 & AGAGAGAGAGAGAGAGC & UBC857 & ACACACACACACACACYG \\
UBC810 & GAGAGAGAGAGAGAGAT & UBC859 & TGTGTGTGTGTGTGTGRC \\
UBC813 & CTCTCTCTCTCTCTCTT & UBC862 & AGCAGCAGCAGCAGCAGC \\
UBC818 & CACACACACACACACAG & UBC864 & ATGATGATGATGATGATG \\
UBC819 & GTGTGTGTGTGTGTGTA & UBC868 & GAAGAAGAAGAAGAAGAA \\
UBC827 & ACACACACACACACACG & UBC873 & GACAGACAGACAGACA \\
UBC834 & AGAGAGAGAGAGAGAGYT & UBC875 & CTAGCTAGCTAGCTAG \\
UBC841 & GAGAGAGAGAGAGAGAYC & UBC879 & CTTCACTTCACTTCA \\
UBC842 & GAGAGAGAGAGAGAGAYG & UBC880 & GGAGAGGAGAGGAGA \\
UBC843 & CTCTCTCTCTCTCTCTRA & UBC881 & GGGGTGGGGTGGGGTG \\
UBC845 & CTCTCTCTCTCTCTCTRG & UBC889 & DBDACACACACACACAC \\
UBC848 & CACACACACACACACARG & UBC890 & VHVGTGTGTGTGTGTGT \\
UBC849 & GTGTGTGTGTGTGTGTYA & UBC895 & AGGTCGCGGCCGCNNNNNNAT \\
UBC854 & TCTCTCTCTCTCTCTCRG & UBC899 & CATGGTGTTGGTCATTGTTCCA \\
UBC855 & ACACACACACACACACYT & & \\
\hline
\end{tabular}


Table 3 - List of the 40 pairs of SSR primers used for molecular characterization of Coffea arabica e Coffea canephora.

\begin{tabular}{|c|c|c|}
\hline Primer & Forward primer (5'-3') & Reverse primer (5'-3') \\
\hline M764* & CTGGCATTAGAAAGCACCTTG & GCTTGGCTCACTGTAGGACTG \\
\hline M793* & CTGAGCGCATGGAAGGAGTA & GGAGACGCAGGTGGTAGAAG \\
\hline M804b & TGGGTTGGTTCTGATTTTGG & ССТСССТСТСТСССТGACTC \\
\hline M747 & CCCCAACCTCATGTCTCTGT & GAGTTTTGCGTGTGTGTGCT \\
\hline CM5* & GTAACCACCACСТCСТCTGC & TGGAGGTAACGGAAGCTCTG \\
\hline CM11 & AATCACCTTCGCAAACCAAC & CCGAACGCAATATCTTATGC \\
\hline CM17 & CCAGCCTTTTCACAATTCTCACCC & TGCCCCCTAGATATGGTACAAGCTTTC \\
\hline CFGA54* & AGTAATGAACCTGCCGCCTCTTT & TTGTCATTCTTGTGTTTTCCATCC \\
\hline CFGA99 & ATTCGACGACTCCAAAGCATA & CCTTGCTGGCCCTTCCTT \\
\hline CFGA189 & CATCCATCCGAAAACTTGTAACG & CAGCACTGGCAAATAGCAACTCTT \\
\hline CFGA222 & GGGACCCACTAGTGCGAAAAG & ССТТАССТТТССААСААСТТСАСА \\
\hline CFGA236 & TTTCTCGTCTTCCATTCCAGT & TGTACCACGTCTATCACCAATG \\
\hline E6-3CTG & CTGGGTTGGTTCTGATTTTG & GGTTCCCAGAGATTCTCTCC \\
\hline $\mathrm{SSRCa} 021 *$ & GCTGAGAGTTTTGAGGGAAA & CCGACGTAGTTGATGATTGA \\
\hline SSRCa033 & GTTTTTACGCGCACGATTA & TTCAAAAGTCAACTCATTCTCC \\
\hline SSRCa040* & AGGGATGTAGAACCAGCAAA & CCAATAGCTCACAACAAAGG \\
\hline SSRCa045 & GACTTGTTGCATTCCCCTA & GCGCATGTGAAGAGAAAGT \\
\hline $\mathrm{SSRCa} 052 *$ & GATGGAAACCCAGAAAGTTG & TAGAAGGGCTTTGACTGGAC \\
\hline SSRCa054* & CCGAACCCAACTAACATCTC & GCAGGTCTTCCATTGTCTGT \\
\hline SSRCa091* & CGTCTCGTATCACGCTCTC & TGTTCCTCGTTCCTCTCTCT \\
\hline SSRCa006* & CTTGCTCAGTGAACCATCC & TGCCTCTTATGCCACTACTAAA \\
\hline SSRCa016 & AGCAGATTCCATCCTTATCCT & CСАCТАATCCATTCCATTCC \\
\hline SSRCa055 & AAGGAAAACAACACCCAAGA & CGAGACAAGAGAGGGGAAA \\
\hline SSRCa061 & GCAGGTGCAAGTGATAAAAG & CGTCTTGTGATGTGTTAGGG \\
\hline SSRCa065 & ATCTAACAAAATCCCCGTCA & ATCGGTCGCCCTTCTAAT \\
\hline SSRCa084* & ATCGGAAAGATGTCAACCAT & CAAATTGAAGCCAGTGGTG \\
\hline SSRCa085* & ATGTGAAAATGGGAAGGATG & CACAGGAAAGTGACACGAAG \\
\hline SSRCa087* & TCACTCTCGCAGACACACTAC & GCAGAGATGATCACAAGTCC \\
\hline SSRCa088* & ТАССТСТССТССТССТТССТ & ATTTCTATGGACCGGCAAC \\
\hline SSRCa095* & GAGAGAGCCGAGTGAAGAGA & GAGAGAGAAGCCATGATTTGA \\
\hline SSRCa096 & GAAATGGTGAACTCTCTCTTGG & ATTTGCATGGCTTTGGTG \\
\hline SSRCa018* & GTCTCGTTTCACGCTCTCTC & ATTTTTGGCACGGTATGTTC \\
\hline SSRM20* & CTTGTTTGAGTCTGTCGCTG & TTTCCCTCCCAATGTCTGTA \\
\hline SSRM24* & GGCTCGAGATATCTGTTTAG & TTTAATGGGCATAGGGTCC \\
\hline SSRM25* & СССТСССТGCCAGAAGAAGC & AACCACCGTCCTTTTCCTCG \\
\hline SSRM32* & AACTCTCCATTCCCGCATTC & CTGGGTTTTCTGTGTTCTCG \\
\hline SSRM3 & АТТСТСТСССССТСТСТG & TGTGTGCGCGTTTTCTTG \\
\hline SSRM11 & ACCCGAAAGAAAGAACCAAG & CCACACAАСТСТССТСАТТС \\
\hline SSRM27 & AGGAGGGAGGTGTGGGTGAAG & AGGGGAGTGGATAAGAAGG \\
\hline SSRM47* & TGATGGACAGGAGTTGATGG & TGCCAATCTACCTACCCCTT \\
\hline
\end{tabular}

*Polymorphic primers

\section{RESULTS}

The analysis of polymorphism of the fragments generated resulted in 307 polymorphic and 24 monomorphic bands. The 331 bands were used in the analyses of similarity between the genetic materials. Of the total number of fragments analyzed, $47 \%$ were polymorphic only for Conilon, 33\% differentiated only the Arabica genotypes and $17 \%$ of the bands were efficient in detecting differences between the genotypes of the two species. There were significant differences between $C$. canephora and $C$. arabica. The analysis of the genetic diversity of $C$. canephora and $C$. arabica by the complement of Jaccard similarity index generated dissimilarity intervals ranging from 0.22 to 0.44 between the Conilon coffee genotypes, 0.02 to 0.28 between the arabica coffee genotypes, and 0.49 to 0.6 between the genotypes of the two species (Fig. 1) 
The molecular bands obtained in this study were also used to construct a dendrogram based on Unweighed Pair Group Method Arithmetic Mean (UPGMA), using the genetic distances between the genotype pairs (Fig. 2). The dendrogram building by the UPGMA method for the 17 genotypes divided them into groups, where the genotypes of each species, $C$. arabica and $C$. canephora, were maintained separated. Considering the origin of the materials, the value 0.60 was used as a cutoff point in the dendogram.

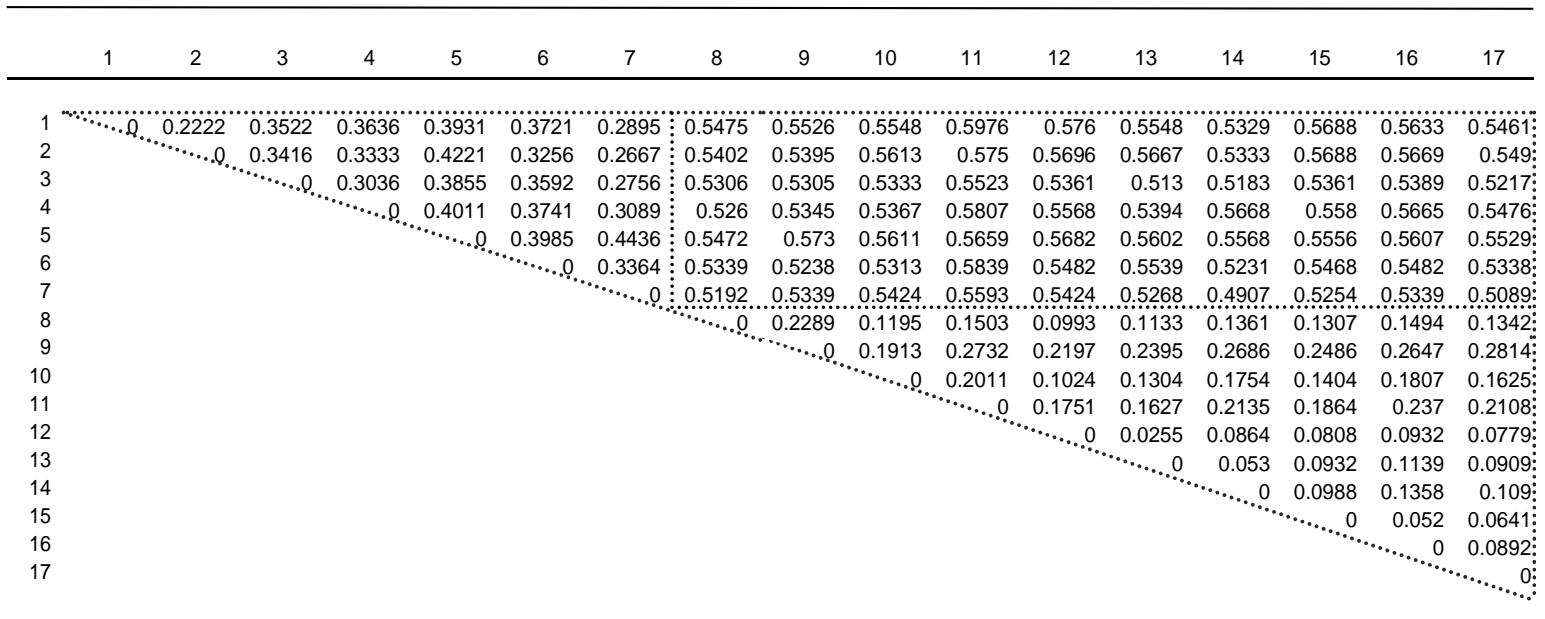

Figure 1 - Genetic dissimilarity building for the 17 Coffea arabica and Coffea canephora genotypes by the Jaccard index.

1- ES03; 2- ES83; 3- ES153; 4- Bukobensi 04; 5- Robusta IAC 2286-3; 6- Robusta Precoce; 7- Conilon JP; 8Bourbon Amarelo; 9- Bourbon Amarelo Nanicão; 10- Icatu Amarelo; 11- Caturra Amarelo; 12- Mundo novo; 13Catuaí Vermelho IAC 81; 14- Iapar 59; 15- Bourbon Vermelho I; 16- Bourbon Vermelho II; 17- Bourbon Vermelho Nanicão. The dotted line delimits the genetic dissimilarity values within $C$. canephora, between $C$. canephora and C. arabica and within C. arabica.

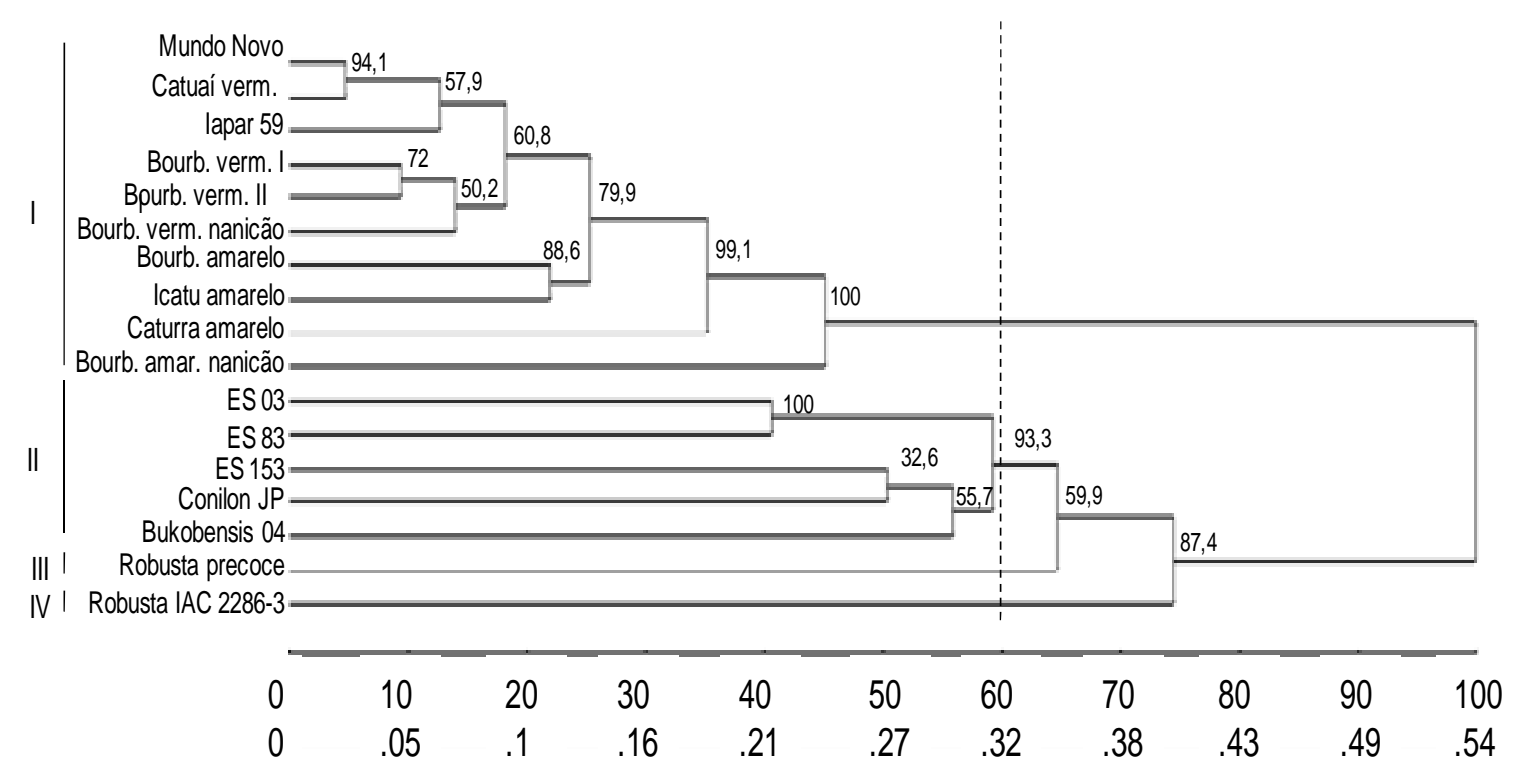

Figure 2 - Dendrogram building by the UPGMA method based on the genetic distances expressed by the Jaccard coefficient index estimated for 17 genotypes of Coffea. 
To validate the results, the optimal number of binary markers was estimated, using the Genes program (Cruz 2008). The correlation was calculated between the Jaccard of $\mathrm{Mi}$, genetic distance matrix, Mi sampled bands $(2 \leq \mathrm{Mi} \leq 307)$, and the original distance matrix with 307 bands. The correlation of 0.9 corresponded to 224 alleles. This number of bands was sufficient to generate a dendrogram similar to that obtained by the 307 bands considered in this study (Fig. 3).

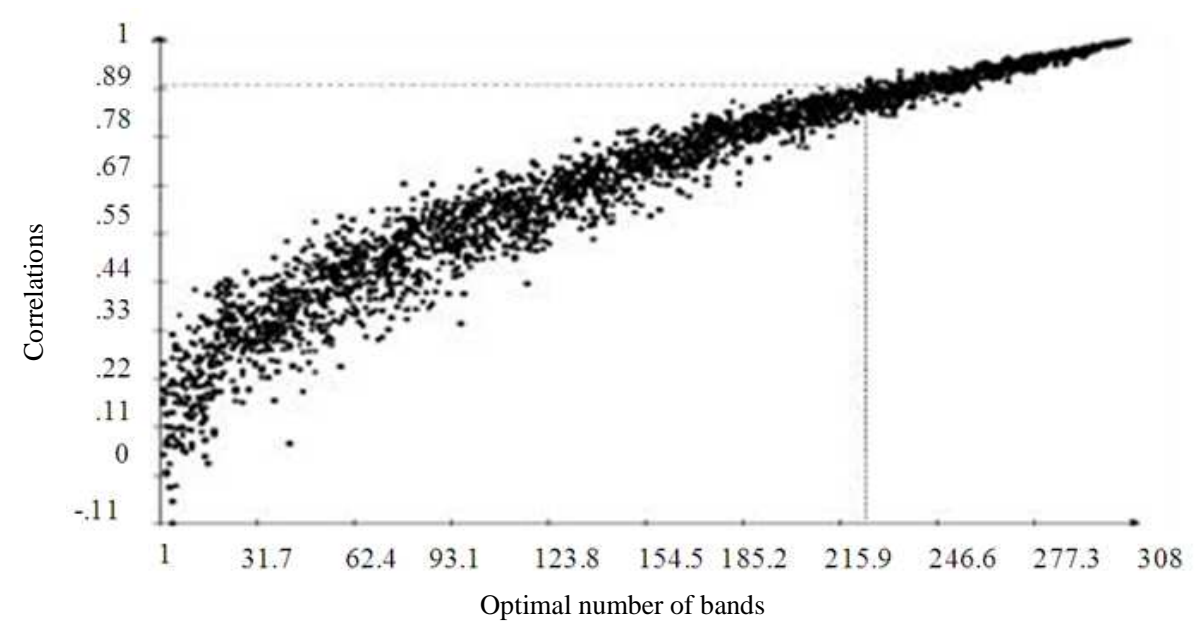

Figure 3 - Optimal number of bands generated by a set of SSR+ISSR primers to assess the genetic diversity of 17 genotypes of Coffea. The dots represent the projection of the correlations between the number of $M_{i}$ bands sampled $\left(2 \leq M_{i} \leq 307\right)$ and the original matrix with $\mathrm{M}$ bands $(\mathrm{M}=307)$.

\section{DISCUSSION}

The low genetic diversity among the $C$. arabica genotypes evaluated was expected. This was due to the process of autogamy and narrow genetic base, resulting from the process of homozygosis and the successive selection cycles (Moncada and Mccouch 2004; Missio et al. 2009b). This was also confirmed by the fact that the arabica genetic materials were probably derived from a few seeds that survived the efforts of expanding the Yemen borders for the cultivation of coffee plants, reaching the present cultivation sites (Vossen 1985).

The $C$. canephora genotypes used in this study showed greater genetic diversity among themselves, with the most dissimilar being $5 \& 7$, $5 \& 2$ and $5 \& 4$, and the most similar being $1 \& 2$, $2 \& 7,3 \& 7$ and $1 \& 7$. The genetic dissimilarity obtained with molecular data for the ES Bukobensis 04 progeny, compared to the Conilon group, was also phenotypically observed in the field (data not published). The considerable genetic variability found in $C$. canephora allowed the selection of superior genotypes for different traits, such as broad adaptation, high yield, plant height, resistance to diseases, pests, abiotic stress, quality, etc. (Hendre and Aggarwal 2007). Despite the low dissimilarity found for $C$. arabica, the ISSR and SSR markers were efficient in distinguishing the genotypes studied and the results obtained were in agreement with the genealogy of the materials.

Based on the cutoff point, four groups were formed. Group I was composed of 'Mundo Novo', 'Catuaí Vermelho', Iapar 59, 'Bourbon Vermelho I', 'Bourbon Vermelho II', 'Bourbon Vermelho Nanicão', 'Bourbon Amarelo', 'Icatu Amarelo', 'Caturra Amarelo', and 'Bourbon Amarelo Nanicão' ; Group II was composed of ES 03, ES 83, ES 153, Conilon JP, Bukobensi 04; group III was composed of 'Robusta Precoce'; and group IV of Robusta IAC 2286-3. The grouping formed was consistent with the origins of each group. High stability of the bifurcations was found by the means of bootstrap analysis per 1000 resamplings, with most presenting values above 50\%. 'Catuaí Vermelho IAC 81' originated from the 'Caturra' $x$ 'Mundo Novo' cross, shared many bands with the parental 'Mundo Novo' and was approximately $30 \%$ distant from 'Caturra Amarelo'. Small genetic differences were 
expected between 'Catuaí' and 'Mundo Novo', as 'Catuaí' originated from the cross between 'Caturra' and 'Mundo Novo' (Carvalho and Monaco 1972). 'Mundo Novo' (Sumatra $x$ 'Bourbon Vermelho') was also grouped with the parental 'Bourbon Vermelho'.

Among the Bourbon progenies used in this study, the molecular bands were efficient in separating 'Bourbon Vermelho', 'Bourbon Vermelho Nanicão', 'Bourbon Amarelo' and 'Bourbon Amarelo Nanicão'. The genetic distance between 'Bourbon Vermelho' and 'Bourbon Amarelo' was due to the fact that the latter originated from the spontaneous cross between the wild cultivars 'Bourbon Vermelho' and 'Amarelo de Botucatu' (Carvalho et al. 1957). This greater genetic variability could be associated with the fact that progeny 'Bourbon Amarelo' was not submitted to intense crossing cycles and selection in the breeding programs (Maluf et al. 2005).

The $C$. canephora genotypes were analyzed in relation to the groups of origin. The grouping was consistent with the origin of the genotypes (Conilon or Robusta). The progenies ES83 and 'Robusta Precoce', which presented phenotypic characteristics intermediary to the two groups (Conilon or Robusta), were more similar to the Conilon genotypes. Among the materials studied, the largest genetic divergence found in the $\mathrm{C}$. canephora species was the progenies 'Robusta IAC 2286-3' and 'Conilon JP', while in the species $C$. arabica, the highest diversity was between 'Bourbon Vermelho Nanicão' and 'Bourbon Amarelo Nanicão'.

\section{CONCLUSIONS}

The use of molecular markers of the SSR and ISSR types in the study of diversity was efficient in carrying out the molecular characterization of coffee genotypes between and within $C$. arabica and $C$. canephora. The results showed that microsatellites markers were efficient in estimating the genetic similarity and could be used to increase the efficiency in classifying the materials and selecting the candidates for parental crosses.

\section{ACKNOWLEDGEMENT}

We thank the Capixaba Research Institute, Technical Assistance and Rural Extension (Instituto Capixaba de Pesquisa, Assistência Técnica e Extensão Rural-Incaper) for supplying the genotypes and the Coffee Biotechnology Laboratory (BioCafé) for supplying the primers.

\section{REFERENCES}

Abdelnoor RV, Barros EG, Moreira MA. Determination of genetic diversity within Brazilian soybean germplasm using random amplified polymorphic DNA techniques and comparative analysis with pedigree. Rev Bras Genét. 1995; 18(2):265-273.

Baruah A, Naik V, Hendre PS, Rajkumar R, Rajendrakumar P, Aggarwal R K. Isolation and characterization of nine microsatellite markers from Coffea arabica (L.) showing wide cross-species amplifications. Mol Ecol Notes. 2003; 3: 647-650.

Carvalho A, Antunes Filho H, Mendes JET, Lazzarini W, Reis AJ, Aloisi Sobrinho J, Moraes MV de, Kerr Nogueira R, Rocha TR. Melhoramento do cafeeiro: XIII - Café Bourbon Amarelo. Bragantia. 1957; 16(28): 411-454.

Carvalho A, Monaco LC. Transferência do fator Caturra para o cultivar "Mundo Novo" de Coffea arabica. Bragantia. 1972; 31: 379-399.

Combes MC, Andrzejewski S, Anthony F, Bertrand B, Rovelli P, Graziosi G, Lashermes P. Characterization of microsatellites loci in Coffea arabica and related coffee species. Mol Ecol. 2000; 9(8):1178-1180.

Coulibaly I, Louarn J, Lorieux M, Charrier A, Hamon $\mathrm{S}$, Noirot M. Pollen viability restoration in a Coffea canephora $\mathrm{P}$. and $C$. heterocalyx Stoffelen backcross. QTL identification for marker-assisted selection. Theor Appl Genet. 2003; 106(2): 311-316.

Cruz CD. Programa Genes: diversidade genética. 1st. ed.Viçosa:UFV; 2008.

Diniz LEC, Sakiyama NS, Lashermes P, Caixeta ET, Oliveira ACB, Zambolim EM, Loureiro ME, Pereira AA, Zambolim L. Analysis of AFLP markers associated to the Mex-1 resistance locus in Icatu progênies. Crop Breed Appl Biot. 2005; 5: 387-393.

Doyle JJ, Doyle JL. Isolation of plant DNA from fresh tissue. Focus. 1990; 12: 13-15.

Ferrão MAG, Fonseca AFA, Ferrão RG, Oliveira AA de, Barbosa WM, D’isep MSP, Barbosa RP. Técnicas moleculares e biotecnológicas aplicadas ao café. 1st. ed. In: Ferrão RG, Fonseca AFA da, Bragança SM, Ferrão MAG, De Muner LH, editors. Café Conilon. 1st. ed. Vitoria, ES: Incaper; 2007. p. 177-201. 
Hendre PS, Aggarwal RK. DNA markers: Development and application for genetic improvement of coffee. In: Varshney RK; Tuberosa R, editors. GenomicsAssisted Crop Improvement - Genomics Applications in Crops; 2007. 2:399-434.

López-Gartner G, Cortina H, Mccouch SR, Moncada $\mathrm{M}$ del P. Analysis of genetic structure in a sample of coffee (Coffea arabica L.) using fluorescent SSR markers. Tree Genet Genomes. 2009; 5(3): 435-446.

Maluf MP, Silvestrini M, Ruggiero LM DE C, Guerreiro Filho O, Colombo CA. Genetic diversity of cultivated Coffea arabica inbred lines assessed by RAPD, AFLP and SSR marker systems. Sci Agric. 2005; 62(4):366-373.

Masumbuko LI, Bryngelsson T. Inter simple sequence repeat (ISSR) analysis of diploid coffee species and cultivated Coffea arabica L. from Tanzania. Genet Resour Crop Ev. 2006; 53(2):357-366.

Mishra MK, Tornincasa P, Nardi B, Asquini E, Dreos R, Del Terra L, Rathinavelu R, Rovelli P, Pallavicini A Graziosi G. Genome organization in coffee as revealed by EST PCR, RFLP, SNPs and SSR analysis. J Crop Sci Biotech. 2011; 14(1):25-37.

Missio RF, Caixeta ET, Maciel-Zambolim E, Zambolim L, Sakiyama NS. Development and validation of SSR markers for Coffea arabica L. Crop Breed Appl Biot. 2009a; 9:361-371.

Missio RF, Caixeta ET, Zambolim EM, Pena GF, Ribeiro AP, Zambolim L, Pereira AA, Sakiyama NS. Assessment of EST-SSR markers for genetic analysis on coffee. Bragantia. 2009b; 68(3):573-581.

Missio RF, Caixeta ET, Zambolim EM, Zambolim L, Cruz CD, Sakiyama NS. Polymorphic information content of SSR markers for Coffea spp. Crop Breed Appl Biot. 2010; 10:89-94.

Moncada P, Mccouch S. Simple sequence repeat diversity in diploid and tetraploid Coffea species. Genome. 2004; 47(3): 501-509.

Poncet V, Hamon P, Minier J, Carasco C, Hamon S, Noirot M. SSR cross-amplification and variation within coffee trees (Coffea spp.). Genome. 2004; 47(6): 1071-1081.
Powell W, Morgante M, Andre C, Hanafey M, Vogel J, Tingey S, Rafalski A. The comparison of RFLP, RAPD, AFLP and SSR markers for germplasm analysis. Mol Breed.1996; 2(3): 225-238.

Rovelli P, Mettulio R, Anthony F, Anzueto F, Lashermes P, Graziosi G. Microsatellites in Coffea arabica L. In: Sera T, Soccol CR, Pandey A, Roussos S, editors. Coffee Biotechnology and Quality, Dordrecht: Kluwer Academic Publishers; 2000. p. 123-133.

Setotaw TA, Caixeta ET, Pena GF, Zambolim EM, Pereira AA, Sakiyama NS. Breeding potential and genetic diversity of "Híbrido do Timor" coffee evaluated by molecular markers. Crop Breed Appl Biot. 2010; 10: 298-304.

Souza SGH De, Carpentieri-Pípolo V, Ruas C De F, Carvalho V De P, Ruas PM, Gerage AC. Comparative analysis of genetic diversity among the maize inbred lines (Zea mays L.) obtained by RAPD and SSR markers. Braz Arch Biol Techn. 2008; 51(1): 183-192.

Tshilenge P, Nkongolo KK, Mehes M, Kalonji A. Genetic variation in Coffea canephora L. (var. Robusta) accessions from the founder gene pool evaluated with ISSR and RAPD. Afr J Biotechnol. 2009; 8(3): 380-390.

Vieira ESN, Von Pinho EV de R, Carvalho MGG, Esselink DG, Vosman B. Development of microsatellite markers for identifying Brazilian Coffea arabica varieties. Genet Mol Biol. 2010; 33(3): 507-514.

Vossen HAM. Coffee selection and breeding. In: Clifford MN and Willson KC, editors. Coffee botany, biochemistry and production of beans and beverage. Croom Helm; 1985. p. 49-96.

Received: June 08, 2013; Accepted: February 18, 2014. 